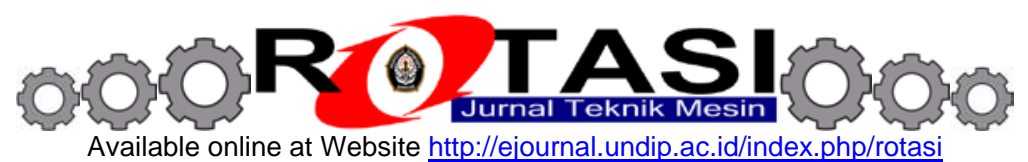

\title{
Pengukuran Koefisien Perpindahan Kalor Evaporasi Refrigeran R-134a di dalam Saluran Halus Horizontal dengan Variasi Kualitas Uap
}

\author{
Tito Hadji Agung Santosa*, Muhammad Nadjib, Thoharudin, Warsito Kabul Suyono \\ Program Studi Teknik Mesin, Fakultas Teknik, Universitas Muhammadiyah Yogyakarta \\ Jl. Lingkar Selatan, Tamantirto, Kasihan, Bantul, Yogyakarta, 55183 \\ *E-mail: titohas@umy.ac.id
}

\begin{abstract}
Abstrak
Nilai koefisien perpindahan kalor evaporasi dari suatu refrigeran sangat penting dalam desain termal evaporator mesin pendingin. Perubahan fasa di dalam evaporator akan terjadi dari fasa cair menjadi fasa uap. Pola aliran yang terbentuk pada proses perubahan fasa tersebut dapat mempengaruhi nilai koefisien evaporasi. Penentuan koefisien evaporasi sulit dilakukan secara teori sehingga mutlak dilakukan secara eksperimental. Penelitian ini bertujuan untuk menentukan koefisien perpindahan kalor evaporasi refrigeran R-134a pada saluran halus horisontal dengan variasi kualitas uap. Alat uji berupa siklus refrigerasi kompresi uap yang dimodifikasi. Perangkat orifice-manometer, pemanas listrik, seksi uji, dan sejumlah termokopel serta indikator tekanan ditambahkan dalam alat uji. Seksi uji berupa pipa ganda aliran berlawanan arah dengan fluida udara sebagai pemanas. Parameter yang diatur adalah laju aliran massa dan kualitas uap dengan beban pendinginan konstan. Laju aliran massa divariasikan dengan menggunakan inverter yang diatur pada frekuensi 14, 16, 18, 20, dan $22 \mathrm{~Hz}$. Inverter dikopel dengan motor listrik sebagai pengerak kompresor. Voltase pemanas listrik divariasikan untuk mengubah kualitas uap refrigeran. Hasil penelitian menunjukkan bahwa dengan memvariasikan kualitas uap, nilai koefisien perpindahan kalor evaporasi naik seiring dengan naiknya kualitas uap pada laju aliran massa yang konstan. Variasi fluks massa tidak secara tegas memberikan hubungan dengan kenaikan nilai koefisien perpindahan kalor evaporasi.
\end{abstract}

Kata kunci: Evaporasi, koefisien perpindahan kalor, kualitas uap, refrigeran R-134a, saluran halus horisontal

\section{Pendahuluan}

Penggunaan sistem pengkondisian udara sudah tidak asing lagi di Indonesia mengingat memiliki iklim tropis. Suhu udara di Indonesia pada siang hari berkisar $28{ }^{\circ} \mathrm{C}-35{ }^{\circ} \mathrm{C}$ dengan kelembaban relatif $70 \%$ - $90 \%$. Kondisi termal udara yang nyaman bagi penghuni di suatu bangunan adalah dengan suhu sekitar $22{ }^{\circ} \mathrm{C}-25{ }^{\circ} \mathrm{C}$ dan kelembaban relatif 40\% - 60\%. Kondisi kenyamanan tersebut dapat diperoleh dengan mengaplikasikan alat pengkondisian udara. Hampir semua sistem pengkondisian udara di Indonesia dilakukan dengan penurunan temperatur dan kelembaban [1].

Perancangan sistem pendingin perlu memperhatikan sifat-sifat fisis dan termis fluida kerja (refrigeran) yang akan digunakan. Refrigeran yang beredar di pasaran ada beberapa jenis berdasar unsur pembentuknya, yaitu: CFC (Chloro Fluoro Carbon), HCFC (Hydro Chloro Fluoro Carbon), HFC (Hydro Fluoro Carbon), dan Hydrocarbon. Refrigeran jenis CFC dan HCFC merupakan zat yang dapat merusak lapisan ozon dan menyebabkan pemanasan global. Refrigeran jenis HFC tidak mengandung unsur Chlor sehingga tidak merusak lapisan ozon [2]. Refrigeran $\mathrm{R}-134 \mathrm{a}$ atau $\mathrm{CH}_{2} \mathrm{FCF}_{3}$ (tetrafloroetana) adalah refrigeran jenis HFC yang tidak beracun, tidak mudah terbakar, tidak mengandung unsur Chlor sehingga tidak memiliki potensi merusak ozon. Refrigeran R-134a, sampai saat ini, masih digunakan secara luas sebagai fluida kerja mesin pendingin.

Evaporator adalah salah satu komponen yang penting dari sistem refrigerasi. Refrigeran mengalami proses perubahan fasa dari fasa cair menjadi fasa uap di evaporator. Koefisien perpindahan kalor evaporasi merupakan parameter yang penting dalam mendesain evaporator. Nilai koefisien perpindahan kalor evaporasi ini mempengaruhi besarnya koefisien perpindahan kalor keseluruhan (U) dan selanjutnya akan menentukan tingkat catu kalor evaporator. Catu kalor evaporator yang tinggi dapat meminimalkan luas permukaan yang diperlukan.

Pengukuran koefisien perpindahan kalor evaporasi pada saluran horisontal sudah pernah dilakukan oleh peneliti sebelumnya dengan berbagai fluida kerja, baik fluida murni atau campuran, dan variasi pengujian. Rhee dan Young meneliti koefisien evaporasi lokal dalam saluran mendatar dengan fluks kalor konstan untuk fluida R 11dan R 12 [3]. Mereka mendapatkan hubungan antara nilai koefisien evaporasi dengan pola aliran yang terjadi. Mereka juga mengamati nilai koefisien evaporasi dan pola aliran yang mengiringi berbeda untuk laju aliran massa rendah dan besar. Santosa meneliti kefisien perpindahan kalor evaporasi refrigeran hidrokarbon yaitu Petrozon Rossy 12 di dalam saluran halus horisontal [2]. Alat yang digunakan adalah sistem refrigerasi kompresi uap sederhana yang dimodifikasi. Hasil penelitian menunjukkan bahwa dengan naiknya kualitas, koefisien evaporasi cenderung turun untuk laju aliran massa refrigeran yang sama. Dalkilic dkk [4] mengkaji koefisien perpindahan kalor evaporasi R-134a pada saluran 
halus horisontal dan vertikal. Seksi uji pada pipa tembaga horisontal memiliki panjang 2,5 m dan diameter 0,81 cm. Fluks massa untuk saluran halus horisontal 300 dan $400 \mathrm{~kg} / \mathrm{m}^{2}$ s. Kualitas uap rata-rata divariasikan antara 0,09 hingga 0,81. Sedangkan untuk saluran vertikal dengan pipa tembaga dengan panjang $0,85 \mathrm{~m}$ dan diameter $0,87 \mathrm{~cm}$. Fluks massa untuk saluran halus vertikal 200 dan $300 \mathrm{~kg} / \mathrm{m}^{2} \mathrm{~s}$. Kualitas uap rata-rata divariasikan antara 0,14 hingga 0,86. Hasil penelitian mengungkapkan bahwa dengan naiknya kualitas uap, nilai koefisien evaporasi akan semakin naik baik pada saluran vertikal maupun horisontal. Namun terhadap variasi fluks massa, nilai koefisien evaporasi pada saluran vertikal menunjukkan adanya pengaruh yang signifikan. Pengaruh variasi fluks massa relatif tidak terlihat pada saluran horisontal.

Penelitian ini melanjutkan penelitian terakhir khususnya untuk saluran horisontal dimana variasi fluks massa dibuat lebih banyak dengan nilai yang lebih rendah. Tujuan penelitian adalah untuk menentukan koefisien perpindahan kalor evaporasi refrigeran R-134a pada saluran halus horisontal dengan variasi kualitas uap.

\section{Material dan metodologi}

Material yang digunakan dalam penelitian ini adalah refrigeran, oli kompresor, air dan udara. Refrigeran yang digunakan adalah R-134a dengan rumus kimia $\mathrm{CH}_{2} \mathrm{FCF}_{3}$ (Tetrafloroetana). Air dipakai sebagai fluida pendingin pada evaporator dan kondenser. Udara berfungsi sebagai pemanas refrigeran di dalam seksi uji sebelum menuju ke evaporator. Oli berfungsi sebagai pelumas kompresor dengan jenis syntetic oil yang compatible dengan refrigeran R134a.

Peralatan yang dipakai adalah siklus refrigerasi kompresi uap dengan modifikasi berupa penambahan komponenkomponen dan alat ukur seperti pada Gambar 1. Inverter digunakan untuk mengatur laju aliran massa refrigeran dengan mengatur kecepatan putar motor listrik dan kompresor. Sistem orifice - manometer dipakai sebagai alat ukur laju aliran massa refrigeran. Pemanas listrik berfungsi untuk mengatur variasi kualitas uap refrigeran dengan bantuan voltage regulator. Seksi uji (Gambar 2) digunakan untuk mengukur koefisien perpindahan kalor evaporasi.

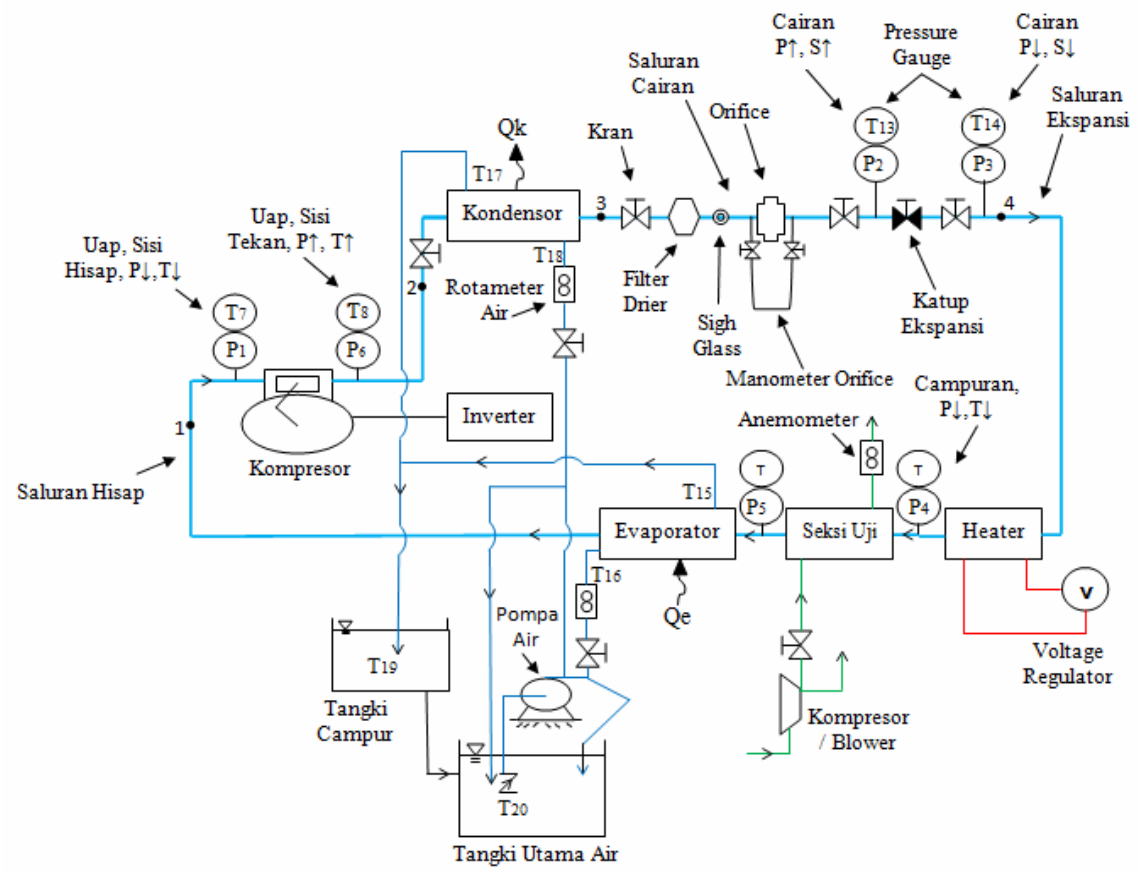

Gambar 1. Skema alat penelitian.

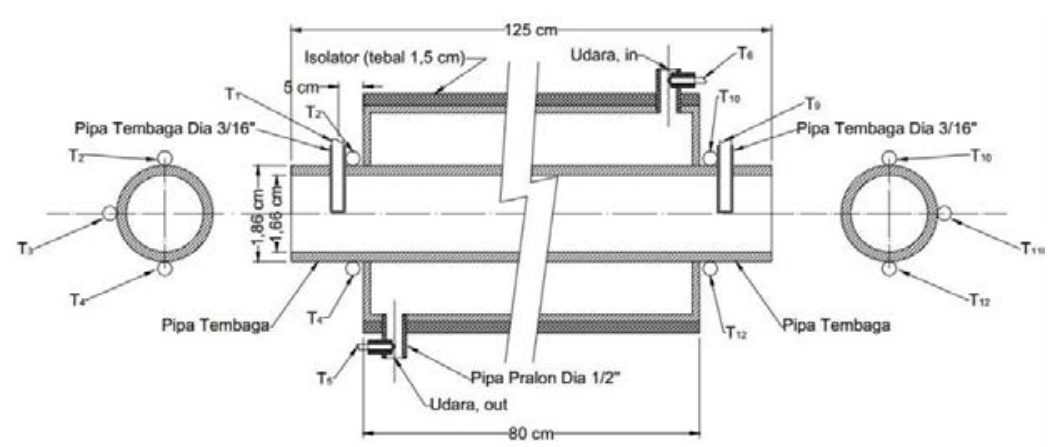

Gambar 2. Seksi uji. 


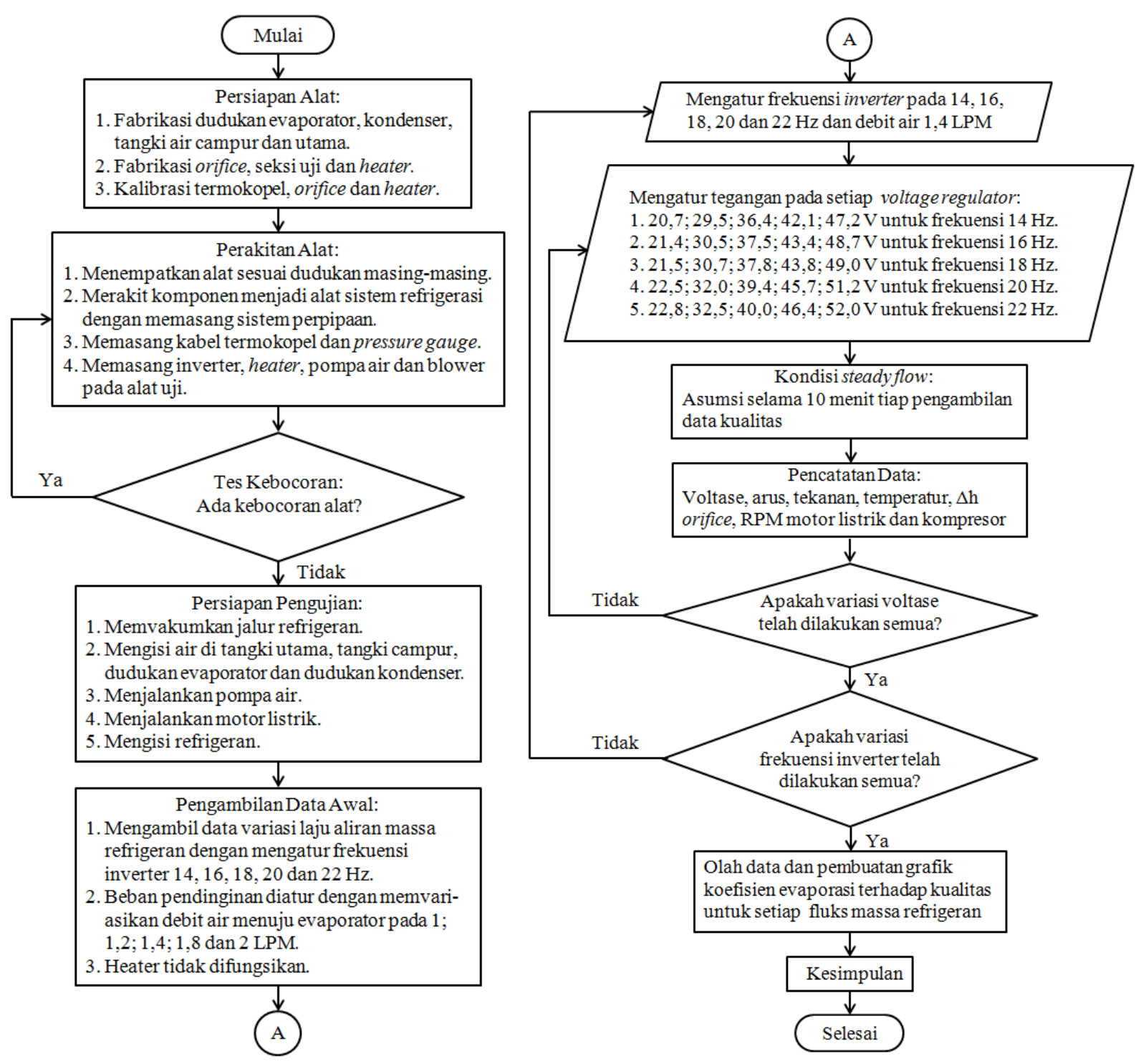

Gambar 3. Diagram alir penelitian.

Penelitian ini dilaksanakan di Laboratorium Konversi Energi Program Studi Teknik Mesin Universitas Muhammadiyah Yogyakarta. Prosedur penelitian dilakukan dengan mengikuti diagram alir seperti disajikan pada Gambar 3. Perhitungan kualitas uap, laju perpindahan kalor evaporasi dan koefisien perpindahan kalor evaporasi dilakukan dengan langkah sebagai berikut.

a. Kualitas Uap $(x)$

Persamaan untuk mengetahui nilai kualitas uap adalah

$$
\begin{aligned}
h_{4^{\prime}} & =\frac{\dot{Q}_{\text {heater }}}{\dot{m}_{\text {refrigeran }}}+h_{3} \\
x & =\frac{h_{4^{\prime}}-h_{f}}{h_{f g}}
\end{aligned}
$$

dimana:

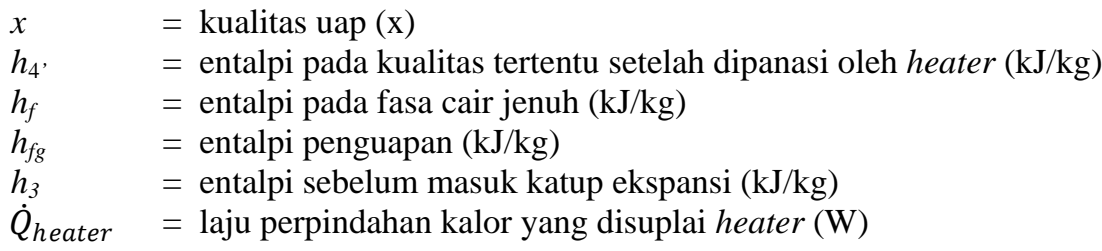


b. Laju perpindahan kalor evaporasi ( $\dot{Q}_{\text {evap }}$ )

Laju perpindahan kalor evaporasi ini sama dengan laju perpindahan kalor yang disuplai oleh udara yaitu:

$$
\begin{aligned}
& \dot{Q}_{\text {evap }}=\dot{m}_{\text {udara }} \cdot c_{p, \text { udara }} \cdot \Delta T_{\text {udara }} \\
& \dot{Q}_{\text {evap }}=\left(\rho_{\text {udara }} \cdot \dot{V}_{\text {udara }}\right) \cdot c_{p, \text { udara }} \cdot\left(T_{\text {udara }, \text { in }}-T_{\text {udara }, \text { out }}\right) \\
& \dot{Q}_{\text {evap }}=\rho_{\text {udara }} \cdot\left(\frac{\pi}{4} D_{\text {i,anemometer }}^{2} \cdot \bar{v}_{\text {udara }}\right) \cdot c_{p, \text { udara }} \cdot\left(T_{\text {udara }, \text { in }}-T_{\text {udara }, \text { out }}\right)
\end{aligned}
$$

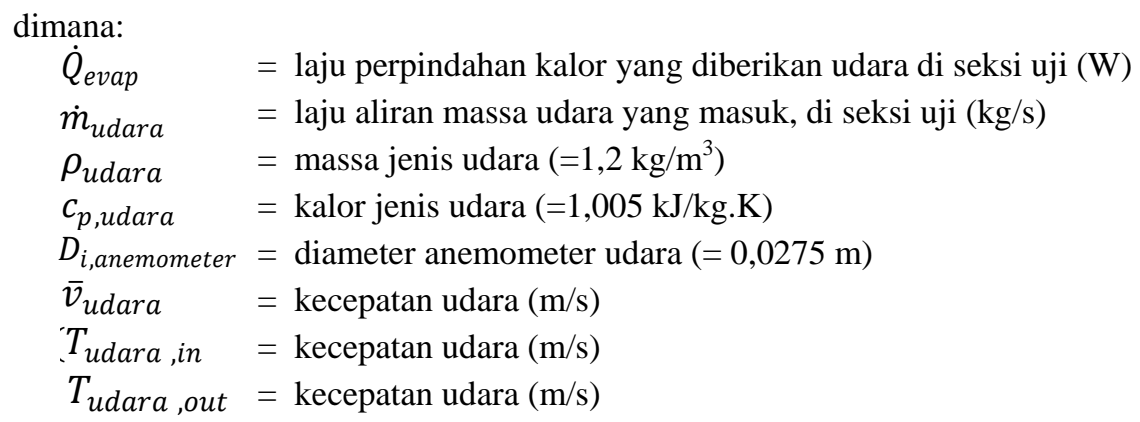

c. Koefisien perpindahan kalor evaporasi $\left(h_{\text {evap }}\right)$

Persamaan yang digunakan untuk menentukan nilai koefisien perpindahan kalor evaporasi adalah

$$
\begin{aligned}
& h_{\text {evap }}=\frac{\dot{Q}_{\text {evap }}}{A_{i} \cdot\left(\bar{T}_{w, i}-\bar{T}_{\text {sat }}\right)} \\
& \bar{T}_{w, i}=\bar{T}_{w, o}-\frac{\dot{Q}_{\text {konduksi }} \cdot \ln \left(\frac{\mathrm{r}_{2}}{\mathrm{r}_{1}}\right)}{2 . \pi \cdot L} \\
& \dot{Q}_{\text {konduksi }}=\dot{Q}_{\text {suplai udara }}=\dot{Q}_{\text {evap }}
\end{aligned}
$$

$$
\begin{array}{cl}
\text { dengan } & \\
A_{i} & =\text { luas permukaan perpindahan kalor }\left(=0,065 \mathrm{~m}^{2}\right) \\
\bar{T}_{w, i} & =\text { temperatur rata-rata dinding dalam saluran }\left({ }^{\circ} \mathrm{C}\right) \\
\bar{T}_{s a t} & =\text { temperatur saturasi rata-rata fluida di saluran }\left({ }^{\circ} \mathrm{C}\right) \\
\bar{T}_{w, o} & =\text { temperatur rata-rata dinding luar saluran }\left({ }^{\circ} \mathrm{C}\right) \\
\mathrm{r}_{2} & =\text { jari-jari luar seksi uji }(=0,93 \mathrm{~m}) \\
\mathrm{r}_{1} & =\text { jari-jari dalam seksi uji }(=0,83 \mathrm{~m}) \\
L & =\text { panjang seksi uji }(=1,25 \mathrm{~m})
\end{array}
$$

\section{Hasil dan pembahasan}

Hubungan temperatur dinding dalam $\left(\mathrm{T}_{\mathrm{w}, \mathrm{i}}\right)$ terhadap kualitas uap refrigeran untuk beberapa harga fluks massa disajikan pada Gambar 4. Gambar 4 menunjukkan bahwa temperatur dinding dalam saluran mengalami perubahan. Saat kualitas uap rendah hingga sedang, temperatur dinding dalam cenderung sedikit turun dan selanjutnya naik dengan bertambahnya kualitas uap. Hal ini diduga berkaitan dengan pola aliran yang terjadi. Ketika kualitas uap rendah, terjadi pola aliran gelembung dan dinding dalam masih banyak terbasahi oleh refrigeran sehingga temperaturnya relatif rendah. Saat kualitas uap tinggi, terjadi pola aliran cincin dan dinding dalam sedikit terbasahi cairan sehingga temperaturnya relatif lebih tinggi. Kapasitas kalor fasa cair lebih besar daripada fasa uap sehingga dengan fluks kalor pemanasan yang relatif sama. Perubahan temperatur fasa uap lebih besar daripada fasa cair.

Gambar 5 memperlihatkan hubungan antara beda temperatur dinding dalam dengan temperatur jenuh refrigeran $\left(T_{w, i}-T_{\text {sat }}\right)$ terhadap kualitas uap refrigeran untuk beberapa harga fluks massa. Pada saat kualitas uap rendah, mulamula beda temperatur sedikit naik dan beda temperatur akan turun pada kualitas uap yang tinggi. Menurut persamaan (4), dengan menurunnya beda temperatur ini maka koefisien perpindahan kalor akan meningkat. Beda temperatur ( $T_{w, i}-$ $\mathrm{T}_{\mathrm{sat}}$ ) semakin kecil karena terbentuk aliran cincin ketika kualitas uap tinggi. Fluida fasa uap mendominasi di bagian tengah saluran dan sedikit di dinding dalam saluran sehingga beda temperatur tidak besar pada saat kualitas uap tinggi. 


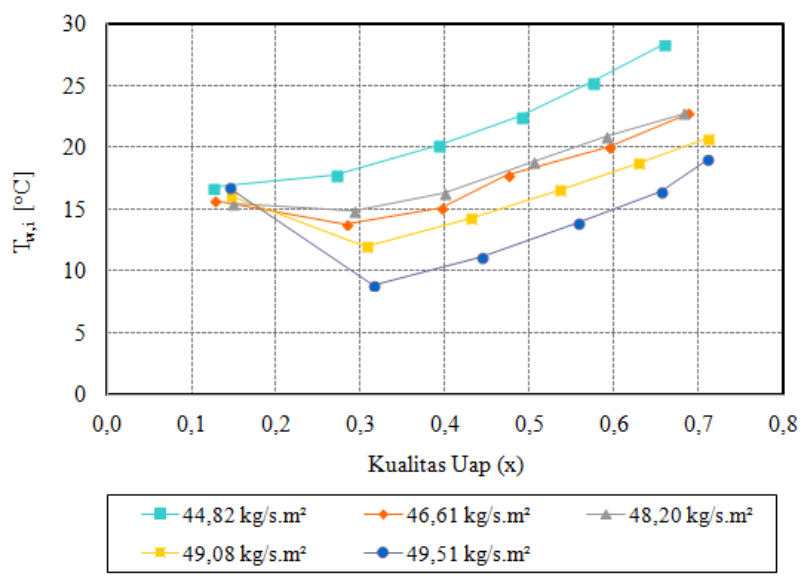

Gambar 4. Hubungan temperatur dinding dalam $\left(T_{\mathrm{w}, \mathrm{i}}\right)$ terhadap kualitas uap refrigeran.

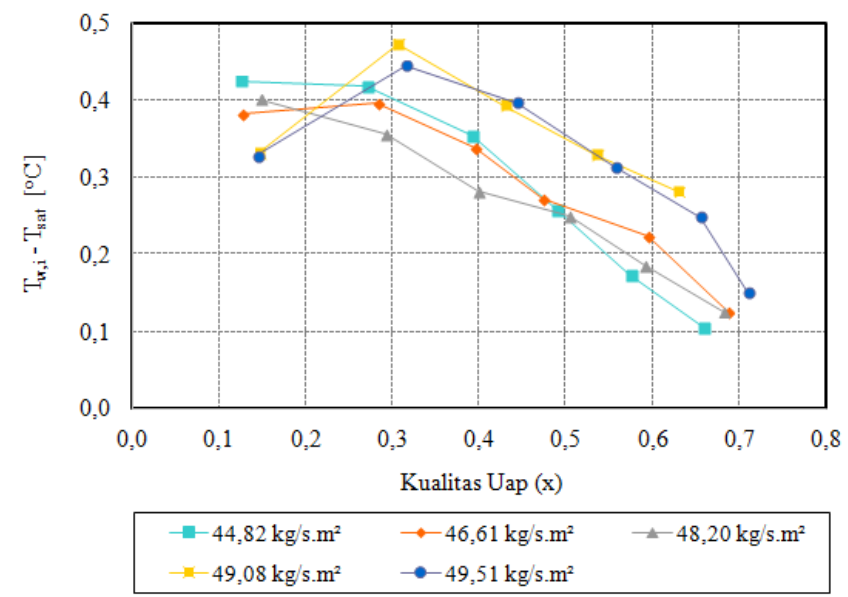

Gambar 5. Hubungan beda temperatur $\left(\mathrm{T}_{\mathrm{w}, \mathrm{i}}-\mathrm{T}_{\mathrm{sat}}\right)$ terhadap kualitas uap refrigeran.

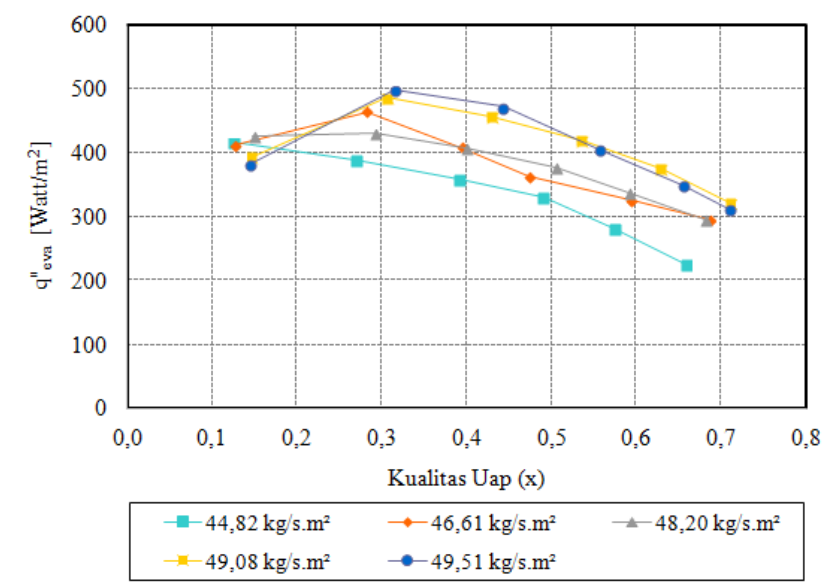

Gambar 6. Hubungan fluks kalor $\left(\mathrm{q}_{\mathrm{eva}}\right)$ ) terhadap kualitas uap refrigeran.

Gambar 6 menunjukkan perubahan fluks kalor terhadap kualitas uap refrigeran untuk beberapa harga fluks massa. Fluks kalor pemanasan pada seksi uji direncanakan konstan yaitu dengan mengalirkan udara pada kecepatan konstan yaitu 3,6 m/s. Akan tetapi fluks kalor menurut Gambar 6 tidak konstan. Perubahan fluks kalor ini diduga terjadi karena adanya fluktuasi aliran udara di sisi anulus pada seksi uji sehingga mempengaruhi pembacaan temperatur udara masuk dan keluar seksi uji. Udara sebagai media pemanas di seksi uji diharapkan menghasilkan perubahan kualitas uap refrigeran yang relatif kecil antara sisi masuk dan sisi keluar seksi uji sehingga diperoleh nilai koefisien evaporasi pada nilai kualitas tertentu. Fluks kalor yang relatif tetap dilakukan memakai elemen pemanas yang dililitkan pada seksi uji dengan mengatur arus dan tegangan listriknya. Namun metode dengan pemanas listrik ini diduga menghasilkan perubahan kualitas uap refrigeran yang relatif lebih besar sehingga tidak sesuai dengan yang diharapkan. 
Hubungan antara nilai koefisien perpindahan kalor evaporasi terhadap kualitas uap untuk berbagai variasi fluks massa ditampilkan pada Gambar 7. Berdasarkan Gambar 7, nilai koefisien perpindahan kalor evaporasi pada saluran halus horisontal cenderung naik dengan naiknya kualitas uap refrigeran untuk berbagai variasi fluks massa. Kenaikan nilai koefisien evaporasi relatif lebih besar untuk nilai kualitas uap yang semakin besar. Hal ini diduga karena pengaruh pola aliran yang terjadi di dalam saluran. Untuk nilai kualitas uap rendah hingga sedang, terjadi pola aliran gelembung (bubbly flow) dan aliran sumbat (plug flow) seperti ditunjukkan pada Gambar 8. Sedangkan pada nilai kualitas uap sedang hingga tinggi, terjadi pola aliran kantong (slug), aliran bergelombang (wavy) dan aliran cincin (annular). Tingkat turbulensi pada pola aliran tersebut diduga semakin besar dengan naiknya nilai kualitas uap sehingga pertukaran kalor semakin baik dan nilai koefisien evaporasi semakin meningkat. Gambar 7 juga menunjukkan bahwa variasi fluks massa tidak secara tegas memberikan hubungan dengan kenaikan koefisien evaporasi. Hal ini sesuai dengan hasil penelitian Dalkilic dkk [4] seperti ditunjukkan pada Gambar 9. Variasi fluks massa tidak terlalu signifikan dalam peningkatan nilai koefisien evaporasi pada saluran halus horisontal jika dibandingkan dengan saluran vertikal. Dalkilic dkk menggunakan variasi fluks massa 300 dan $400 \mathrm{~kg} /\left(\mathrm{m}^{2} . \mathrm{s}\right)$ pada saluran halus horisontal. Beda variasi fluks massa pada penelitian Dalkilic dkk jauh lebih besar daripada beda variasi laju aliran massa yang dihasilkan dalam penelitian ini yaitu $0,0097-0,01072 \mathrm{~kg} / \mathrm{s}$ atau $44,82-49,51 \mathrm{~kg} /\left(\mathrm{m}^{2} . \mathrm{s}\right)$ sehingga dengan variasi frekuensi inverter pada penelitian ini tidak menghasilkan kesimpulan tentang pengaruhnya terhadap koefisien evaporasi. Untuk mendapatkan variasi fluks massa yang lebih besar sebaiknya menggunakan pompa refrigeran sebagai pengganti kompresor.

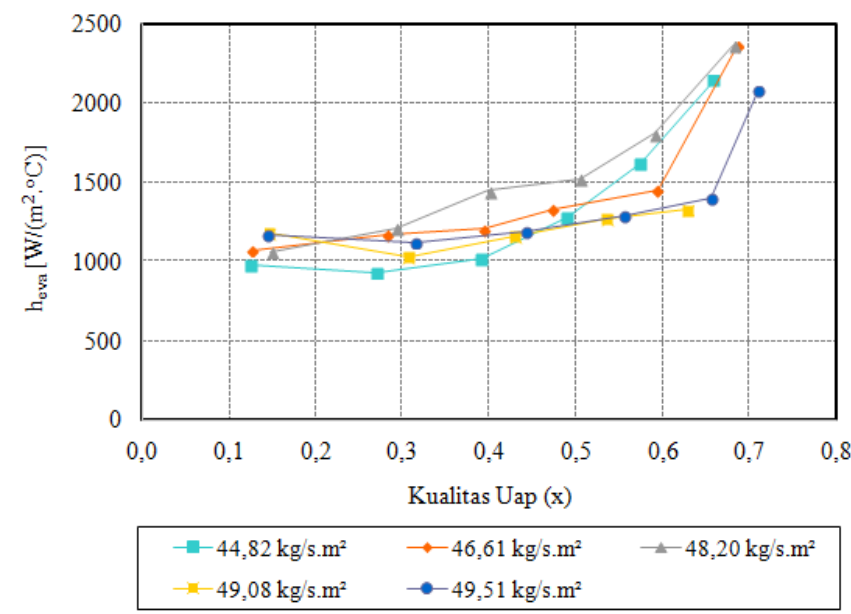

Gambar 7. Hubungan koefisien perpindahan kalor evaporasi $\left(\mathrm{h}_{\mathrm{evap}}\right)$ di dalam saluran halus horisontal terhadap kualitas uap refrigeran.

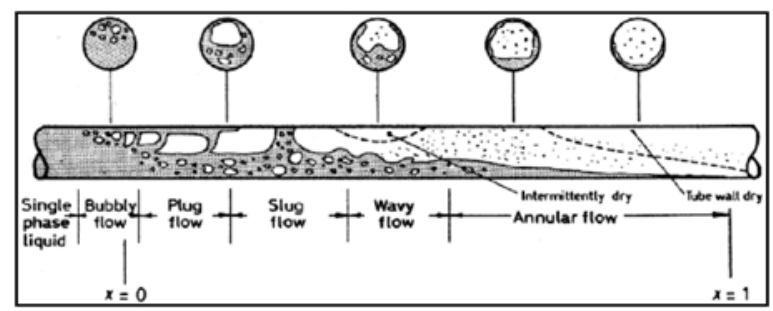

Gambar 8. Pola aliran evaporasi di dalam saluran horisontal [5].

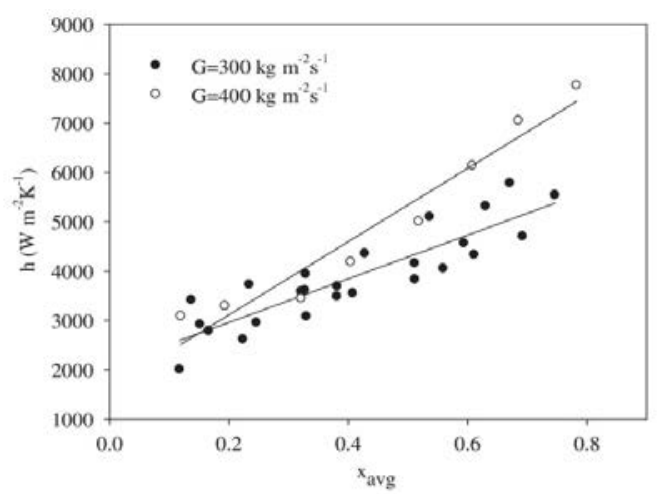

Gambar 9. Hubungan antara koefisien evaporasi dengan variasi kualitas uap pada saluran halus horisontal [4]. 


\section{Kesimpulan}

Telah dilakukan penelitian tentang pengukuran koefisien perpindahan kalor evaporasi refrigeran R-134a dengan variasi kualitas uap di dalam saluran halus horisontal. Variasi kualitas uap dilakukan dengan mengatur laju aliran massa refrigeran. Pengaturan frekuensi inverter dipilih untuk memvariasikan laju aliran massa. Kesimpulan dari penelitian ini adalah:

a. nilai koefisien perpindahan kalor evaporasi refrigeran R-134a semakin besar dengan naiknya nilai kualitas uap. Laju kenaikan nilai koefisien evaporasi ketika kualitas uap tinggi adalah lebih besar daripada saat kualitas uap rendah;

b. variasi laju aliran massa refrigeran dengan alat uji sistem refrigerasi kompresi uap tidak memberikan hasil peningkatan nilai koefisien perpindahan kalor evaporasi yang signifikan;

c. nilai koefisien perpindahan kalor evaporasi berada antara nilai $929,17 \mathrm{Watt} /\left(\mathrm{m}^{2} .{ }^{\circ} \mathrm{C}\right)$ pada fluks massa 44,82 $\mathrm{kg} /\left(\mathrm{m}^{2} . \mathrm{s}\right)$ dan kualitas uap 0,27 hingga $2.362,31 \mathrm{Watt} /\left(\mathrm{m}^{2} .{ }^{\circ} \mathrm{C}\right)$ pada fluks massa $46,61 \mathrm{~kg} /\left(\mathrm{m}^{2} . \mathrm{s}\right)$ dan kualitas uap 0,69 .

\section{Referensi}

[1] Wahyuadi, T., 2012, “Pengaruh Tekanan Refrigeran Pada Heat Pipe R134a dan R22 Terhadap pengkondisian udara”, Program Studi Teknik Mesin, Universitas Indonesia.

[2] Santosa, T.H.A., 2003, "Pengukuran Koefisien Perpindahan Kalor Evaporasi Refrigeran Petrozon Rossy 12 di Dalam Saluran Halus Horisontal”, Program Pascasarjana, Universitas Gajah Mada.

[3] Rhee, B. W. dan Young, E. H., 1974, "Heat Transfer to Boiling Refrigerants Flowing inside a Plan Copper Tube", AIChE Symposium Series, No.138 Vol. 70, New York.

[4] Dalkilic, A.S., Celen, A., Cebi, A. dan Wongwises, S., 2016, "Empirical Corelation for The Determination of R134a's Convective Heat Transfer Coeficient In Horizontal and Vertical Evaporators Having Smooth and Corrugated Tube”, International Communications in Heat and Mass Transfer, 76: 85-97.

[5] Collier, J.G., 1981, “Convective Boiling and Condensation”, 3rd ed., McGraw-Hill Int. Book Co., New York.

\section{Ucapan Terima Kasih}

Penulis mengucapkan terima kasih kepada LP3M Universitas Muhammadiyah Yogyakarta atas terlaksananya Penelitian Unggulan Prodi ini sesuai Kontrak No. 1091/SP2-PL/LP3M-UMY/2017. 